\title{
The mineralocorticoid receptor and its coregulators
}

\author{
Jun Yang ${ }^{1,2}$ and Morag J Young ${ }^{1}$ \\ ${ }^{1}$ Prince Henry's Institute of Medical Research and ${ }^{2}$ Department of Medicine, Monash University, PO Box 5152, Clayton, Victoria 3168, Australia
}

(Correspondence should be addressed to M J Young; Email: morag.young@ princehenrys.org)

\begin{abstract}
The mineralocorticoid receptor (MR) is a member of the nuclear receptor superfamily and is essential for controlling sodium transport in epithelial tissues such as the kidney and colon. Moreover, it is also present in other non-epithelial tissues and is capable of activation by both mineralocorticoids and glucocorticoids. A challenge in understanding transcriptional regulation by the MR and other nuclear receptors is to determine how tissue- and ligand-specificity is achieved. Over the past decade, it has become clear that a heterogeneous group of non-receptor proteins termed as coregulators are required to either enhance or repress nuclear receptor-mediated transactivation of target genes. A subset of these coregulators may be expected to confer specificity to MR-mediated responses by virtue of their variable tissue expression and selectivity for different ligands. Specific coregulator-MR interactions may be a suitable target in the rational design of tissue-specific MR modulators as has been described for other steroid receptors. However, the number of coregulators identified to date for the MR is very limited compared with other nuclear receptors. Understanding the full complement of MR coregulators is essential for unraveling the complexity of MR signaling pathways and will facilitate the development of selective MR modulators.
\end{abstract}

Journal of Molecular Endocrinology (2009) 43, 53-64

\section{Introduction}

The mineralocorticoid receptor (MR) is a nuclear receptor (NR) that is critical for controlling sodium and potassium transport in epithelial cells, most notably in the kidney and colon (Pearce et al. 2003). It also plays important roles in non-epithelial tissues, such as cardiac myocytes, blood vessels, the hippocampus and adipose tissue (Lombes et al. 1992, 2000, Meijer 2002, Caprio et al. 2007). The MR is capable of binding multiple classes of steroids with high affinity, including the mineralocorticoids, aldosterone and deoxycorticosterone, the glucocorticoids (GR), cortisol (in humans) or corticosterone (in rodents), and progesterone (PR; Sutanto \& de Kloet 1991). While aldosterone is considered the primary physiological MR ligand in humans (Bledsoe $e$ t al. 2005), in some tissues cortisol may be the primary ligand for MR, whereas PR behaves as a predominant antagonist (Fagart et al. 1998).

MR activation plays an important role in the pathophysiology of hypertension and cardiac fibrosis (Young \& Funder 2000, Fagart et al. 2005). Two large clinical trials, the randomized aldactone evaluation study (Pitt et al. 1999), and Eplerenone Post-Acute Myocardial Infarction Heart Failure Efficacy and Survival Study (Pitt et al. 2003), have demonstrated that MR blockade can significantly reduce morbidity and mortality in patients with heart failure. However, the underlying molecular mechanisms of these beneficial effects remain unknown. Furthermore, the use of MR antagonists is limited by the adverse renal effect of hyperkalemia (Juurlink et al. 2004). A tissue-selective MR antagonist that only targets heart failure while avoiding unwanted renal effects would thus be highly desirable. This is just one example of the myriad potential applications of a tissue-selective MR modulator. Others may exploit the anti-apoptotic role of MR in hippocampal degeneration (de Kloet et al. 2005) or seek to counteract the induction of endothelial dysfunction and vascular injury by aldosterone (Sugiyama et al. 2005).

For other NRs, studies have revealed numerous coregulator molecules that serve to coordinate the interaction between the NR and their target genes and in some cases define ligand- or tissue-specificity (Rowan \& O'Malley 2000, Chang \& McDonnell 2005, Hall \& McDonnell 2005, Heemers \& Tindall 2007). The search for MR-interacting coregulators is less advanced, partly due to the difficulty in purifying stable full-length MR (Clyne et al. 2009). This review examines the available literature on MR coregulators with a view to understand their role in the ligand- and tissue-specific activation of the MR, and their potential as therapeutic targets, as well as identifying areas for further research.

DOI: 10.1677/JME-09-0031 Online version via http://www.endocrinology-journals.org 


\section{The mineralocorticoid receptor}

The MR (NR3C2) is the longest member of the NR family of ligand-dependent transcription factors (Bookout et al. 2006). It belongs to the oxosteroid receptor subgroup that comprises of the androgen (AR), GR, and PR receptors (Bledsoe et al. 2005) although it is most closely related to the GR with which it shares a common ancestor (Baker et al. 2007, Ortlund et al. 2007). In the absence of ligand, MR resides in the cytosol and is rendered transcriptionally inactive by a variety of chaperone proteins including the $90-\mathrm{kDa}$ heat shock protein (hsp90; Gomez-Sanchez et al. 2006). Ligand binding induces a conformational change in the MR resulting in its dissociation from the chaperone proteins, homodimerization, and translocation to the nucleus where it directs the transcription of target genes (Fig. 1; Lombes et al. 1994a, Hellal-Levy et al. $2000 a$ ). In addition to the classic pathway of genomic action, rapid, non-genomic action of MR signaling has also been described, in particular in terms of activation of protein kinase $\mathrm{C}$ and $\mathrm{Na}^{+} / \mathrm{H}^{+}$exchange and increased intracellular calcium (Losel \& Wehling 2003, Mihailidou et al. 2004, Funder 2005). However, this will not be discussed further as the mechanism of non-genomic action has not yet been shown to involve coregulators.

The MR contains the three principal domains characteristic of the NR superfamily: the N-terminal domain (NTD) or A/B region, the DNA-binding domain (DBD) or $\mathrm{C}$ region, and the C-terminal ligand binding domain (LBD) or $\mathrm{E}$ region (Rogerson et al. 2003). A flexible hinge exists between the DBD and

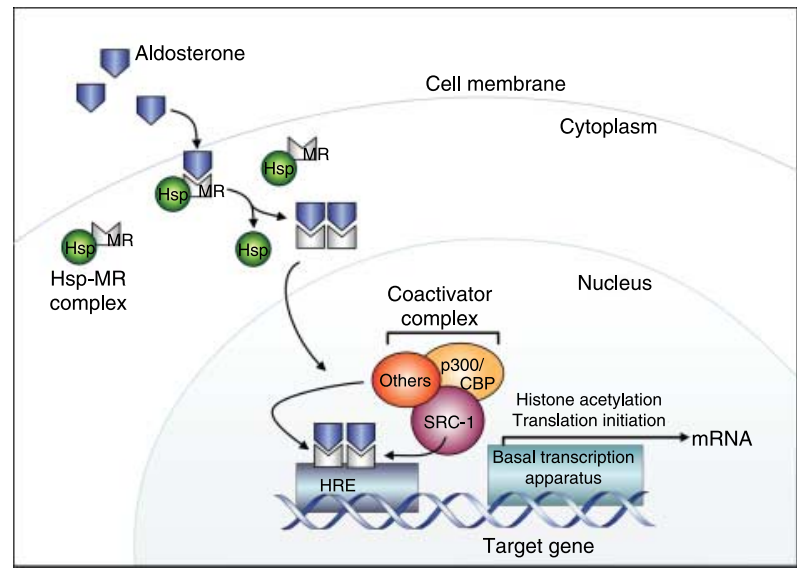

Figure 1 Schematic representation of MR signaling upon agonist ligand binding. The MR dissociates from hsp, which hold it inactive in the cytoplasm, and translocates to the nucleus where it binds to a HRE. Coactivators, such as SRC-1 and p300/CBP, are sequentially recruited to the MR to allow histone acetylation and target gene transcription to occur. MR, mineralocorticoid receptor; hsp, heat shock protein; HRE, hormone response element. The reader is referred to the text for full names of coregulators.

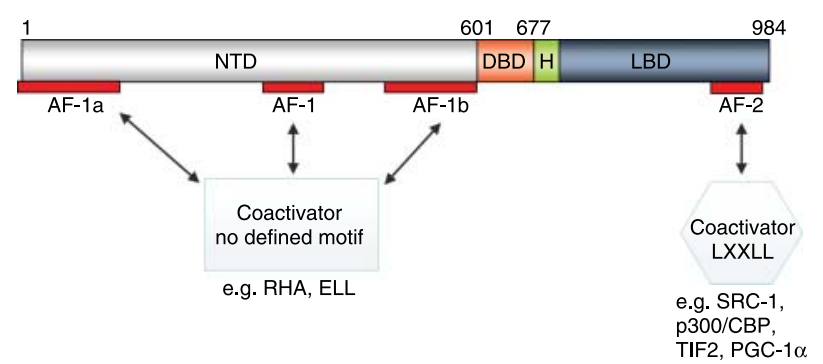

Figure 2 Schematic representation of the human MR structure displaying sites of interaction with coactivators. AF-2 is well defined and consists of parts of helices 12, 3, 4, and 5 which interact with the LXXLL motif of coactivators. AF-1 is poorly defined, and is separated into AF1a and AF1b by some groups. There is no consensus motif for coactivator binding to AF-1. MR, mineralocorticoid receptor; AF-2, activation function-2; AF-1, activation function-1. The reader is referred to the text for details on MR structure and full names of the coregulators.

LBD or D-region, but its function is poorly defined (Rogerson \& Fuller 2003). For a more detailed review of MR's structure, see Pippal \& Fuller (2008). As the LBD and the NTD are of particular relevance to coregulators, they will be further explored here (Fig. 2).

The MR LBD is conserved between species and has multiple functions, including ligand binding, nuclear localization, dimerization, interaction with hsps, and transcriptional coactivators and ligand-dependent transactivation via an activation function (AF), or AF-2, domain (Wurtz et al. 1996, Farman \& RafestinOblin 2001). It consists of $11 \alpha$-helices with four $\beta$-strands folded into an antiparallel three layered sandwich (Bledsoe et al. 2005, Fagart et al. 2005, $\mathrm{Li}$ et al. 2005). The crystal structure of the MR LBD reveals that aldosterone is bound in a fully enclosed pocket contacting residues in helices $3,4,5,6,7$, and 11 and the $\beta$-turn (Bledsoe et al. 2005). Upon agonist binding, helix 12 is repositioned together with helices 3,4 , and 5 to form a hydrophobic groove on the surface of the LBD which allows binding of coactivators and subsequent MR activation (Geller et al. 2000, HellalLevy et al. 2000b, Bledsoe et al. 2005, Li et al. 2005). It is important to note that helix 12 alone is not the AF-2; rather it constitutes part of an activation surface which, together with other parts of the LBD, defines the AF-2 domain (Alnemri et al. 1991, Darimont et al. 1998).

The NTD is the least conserved domain among NRs, both in size and sequence (Warnmark et al. 2003). The MR has the longest NTD which shares less than $15 \%$ homology with the GR NTD (Alnemri et al. 1991). The MR NTD contains the constitutive AF-1 which differs from AF-2 by being ligand-independent and intrinsically disordered in its structure (Warnmark et al. 2003, Lavery \& McEwan 2005). One study localized AF-1 to amino acids 328-382 (Govindan \& Warriar 1998) while other studies separated the AF-1 into two different regions, AF-1a (amino acids 1-169) and AF-1b (amino 
acids 451-600; the 147 amino acids next to the DBD), separated by an inhibitory domain (Fuse et al. 2000, Pascual-Le Tallec et al. 2003). It is postulated that the intrinsic lack of structure of the NTD allows unique secondary structure formation which permits interaction with specific coregulators (McEwan et al. 2007). The MR NTD also contains four consensus sumoylation motifs, with a fifth one in the LBD. These lysine acceptor sites allow post-transcriptional modification of the MR (Seeler \& Dejean 2003) and transcriptional repression at certain response elements (Tallec \& Lombes 2005).

\section{Mechanisms of MR specificity}

As noted, the MR can be activated by both mineralocorticoids and GRs, with distinct actions in different tissues. The mechanisms by which the MR achieves differential activation by the two corticosteroid hormones and exerts tissue-specific effects can be considered at the pre-receptor, receptor, and post-receptor levels. These three levels are well illustrated in Fig. 2 of the review by Pascual-Le Tallec et al. (2005).

Pre-receptor metabolism of cortisol is a key mechanism for maintaining MR selectivity in certain target tissues. Type $211 \beta$-hydroxysteroid dehydrogenase (11ß-HSD2) converts cortisol, which circulates at concentrations 100- to 1000-fold higher than those of aldosterone $(0 \cdot 1-1 \mathrm{nM})$, to inactive cortisone, thereby protecting the MR from inappropriate activation by cortisol (Edwards et al. 1988, Funder et al. 1988, Bocchi et al. 2003, Galigniana et al. 2004). However, this mechanism is only present in the epithelial cells of the distal nephron, colon, sweat glands, and blood vessel walls (Alzamora et al. 2000, Christy et al. 2003, Galigniana et al. 2004). 11ß-HSD2 expression is minimal or absent in other MR-expressing tissues including the myocardium and hippocampus.

At a receptor level, mineralocorticoid selectivity is conferred by ligand induced conformational changes that differ between cortisol and aldosterone. It has been demonstrated that aldosterone dissociates more slowly from MR and induces greater transactivation than cortisol at any given concentration (Lombes et al. 1994b, Farman \& Rafestin-Oblin 2001). Moreover, the interaction between the MR NTD and the C-terminal hinge and LBD (or the $\mathrm{N}-/ \mathrm{C}$-interaction), which may serve to stabilize ligand binding to the receptor (Li et al. 2006, Centenera et al. 2008), is much stronger in the presence of aldosterone than cortisol, offering another mechanism of ligand specificity at the MR (Rogerson \& Fuller 2003).

Receptor isoforms are also believed to generate diversity in tissue-specific receptor response. This has been well demonstrated for the GR which has multiple potential isoforms, derived from the one gene, which are capable of producing unique biological responses to the same hormone in different tissues (Yudt \& Cidlowski 2002, van der Laan \& Meijer 2008). Transcription of the MR can be directed by two functional promoters, $\mathrm{P} 1$ and $\mathrm{P} 2$, to generate the isoforms hMR- $\alpha$ and hMR- $\beta$ that differ in the $5^{\prime}$-untranslated region (Zennaro et al. 1996) and display differential tissue expressions (Zennaro et al. 1997). Furthermore, both promoters are found to be inducible by GRs, whereas only P2 appears sensitive to mineralocorticoids, suggesting that ligand-specificity may also be determined by the particular MR isoform generated. Another splice variant of the MR is hMR 55,6 (Zennaro et al. 2001), which will be discussed later in this review.

At the post-receptor level, an expanding library of over 300 NR coregulators has been identified over the past decade (Lonard 2007). They have been recognized to play a central role in modulating gene expression mediated by NRs and are thought to impart tissue- and ligand-specificity due to their structural and functional diversity (Lonard \& O’Malley 2006).

\section{Nuclear receptor coregulators: an overview}

NR coregulators are comprised of both coactivators and corepressors and are defined as cellular factors which interact with NRs to potentiate or attenuate transactivation (McKenna \& O'Malley 2000).

Steroid receptor coactivator 1 (SRC-1) was the first NR coregulator identified over a decade ago (Onate et al. 1995). Coactivators function as large complexes which are recruited to the target gene by NRs following ligand binding and perform many of the enzymatic reactions needed for gene expression including chromatin remodeling, histone modification, initiation of transcription, elongation of RNA chains, RNA splicing, and termination of transcriptional responses (Auboeuf et al. 2002, O'Malley 2007). They can also serve as docking platforms for further coregulator binding (McInerney et al. 1998). The ordered and cyclical recruitment of coregulator complexes have been elegantly illustrated for estrogen receptor- $\alpha$ (ER- $\alpha$; Metivier et al. 2003). Many coactivators bind the AF-2 region of the LBD via a conserved NR-box that contains one or more LXXLL (where $\mathrm{L}$ is leucine and $\mathrm{X}$ is any amino acid) motifs (Heery et al. 1997, Darimont et al. 1998). Sequence conservation, however, has not been observed in AF-1 binding coactivators; they do not appear to require the LXXLL motif (Warnmark et al. 2003).

By contrast, corepressors interfere with transactivation by inducing histone deacetylase activity and other mechanisms to inhibit the general transcriptional machinery (Goodson et al. 2005). The nuclear receptor corepressor (NCoR) and silencing mediator of 
retinoid and thyroid hormone receptor (SMRT) were the first corepressors discovered on the basis of their ability to bind ligand-free thyroid hormone receptor (TR) and reduce the total amount of gene product (Chen \& Evans 1995, Horlein et al. 1995). Corepressors bind the LBD of an unliganded NR via a C-terminal 'CoRNR box' motif, defined as I/L-XX-I/V-I and recruit histone deacetylase proteins to repress gene expression (Hu \& Lazar 1999). Ligand binding leads to an exchange of corepressors for coactivators, thereby allowing transcription to occur (Perissi et al. 2004). More recently, corepressors have been found to also interact with antagonist-bound NRs including the $\mathrm{AR}, \mathrm{ER}, \mathrm{GR}$, and PR as well as the agonist-bound GR, suggesting that it is the ratio of coactivators to corepressors bound to a NR-ligand complex that modulates the transcriptional sensitivity of the NR (Wang et al. 2004b).

While most of the coregulators identified are widely expressed (Smith \& O'Malley 2004), some display tissue-specific expression patterns and limit NR-mediated gene transcription to those tissues that express the required coactivators (Knutti et al. 2000, Ko et al. 2002). For example, the expression of SRC-1 is significantly higher in Ishikawa endometrial carcinoma cells compared with MCF-7 breast cancer cells and this can be correlated with the increased agonist activity of tamoxifen (a selective ER modulator, SERM) in Ishikawa cells (Shang \& Brown 2002). Moreover, SRC-1 is specifically required for the agonist activity of tamoxifen, but not essential for other ligands such as estradiol, thereby permitting ligand-specific ER activation (Shang \& Brown 2002).

Variation in the binding motif configuration of coregulators may also confer specificity. SRC-1 contains three LXXLL motifs and while a single LXXLL sequence is sufficient for activation of the ER, different combinations of two LXXLL sequences are required for the TR, retinoic acid receptor (RAR), peroxisome proliferator activated receptor (PPAR), and PR (McInerney et al. 1998). Distinct residues flanking the LXXLL motif have also been shown to modulate specific interactions with NRs, although it has not yet been demonstrated for the MR (Darimont et al. 1998, McInerney et al. 1998, Chang et al. 1999). In contrast to other NRs, the preferred binding motifs for AR are FXXLF (Chang et al. 2005) and WXXLF (He et al. 2000). Similar novel consensus sequences have not been described for the MR to date.

\section{Coactivators of the MR}

The AF-2 region of the MR binds LXXLL-containing coactivators, such as SRC-1, with high affinity, as is the case with many other NRs (Hultman et al. 2005). SRC-1 is a member of the p160 coactivator family of proteins (Ding et al. 1998) and while it only possesses weak histone acetyltransferase activity, it can sequentially recruit a chromatin remodeling complex to achieve histone acetylation and initiate transcription (Spencer et al. 1997, Xu \& Li 2003). It is widely expressed in many tissues and cell types, and is reported to have five splice variants, with SRC1a and SRC1e being the most abundantly expressed. SRCla has two functionally separable LXXLL motifs which bind MR with equal preference but bind other NRs with different specificities (Ding et al. 1998). Of note, the binding of SRCla and SRCle to GR and MR exhibits promoter and receptor specificity (Meijer et al. 2005). Coactivation by SRCla is consistently stronger on a single response element-containing reporter, whereas SRCle is stronger when multiple response elements are present. In terms of receptor specificity, SRC1e can enhance transcription via the AF-2 of both GR and MR, but via the NTD only in MR. The selective coactivation of MR by SRC1e in the NTD is hypothesized to be mediated via AF-1, although the exact receptor-coactivator interface has not been characterized (Meijer et al. 2005). The interaction between SRC-1 and MR does not appear to exhibit ligand specificity as the MR LBD interacts equally with an SRC-1 peptide in the presence of different steroid hormones (Hultman et al. 2005), although the result may be different if a full-length MR or SRC-1 is used.

Often complexed with SRC-1 are the global transcriptional coactivators and functional homologues p300 and CBP. p300/CBP possess strong intrinsic histone acetyltransferase activity and the ability to recruit RNA polymerase II to target gene promoters (Ogryzko et al. 1996). They are able to potentiate the transcriptional activity of MR via both AF-1 and AF-2. However, there is no direct interaction between p300/CBP and AF-1, raising the possibility of another intermediary nuclear factor (Fuse et al. 2000). Of interest, CBP has been found to facilitate hormone-induced $\mathrm{N}-/ \mathrm{C}$-interaction in the AR (Ikonen et al. 1997), and perhaps the ability to engage both AF-1 and AF-2 in the MR contributes to the $\mathrm{N}-/ \mathrm{C}-$ interaction of the MR.

SRC-2 (or transcriptional intermediary factor 2, TIF2) is another member of the p160 coactivator family that can bind the MR (Voegel et al. 1996, Ding et al. 1998). It shows widespread tissue expression with the exception of the kidney, skeletal muscle, and mammary gland ( $\mathrm{Xu}$ \& Li 2003). SRC-2 has been shown to contain three partially redundant LXXLL motifs and mediate part of its action through CBP recruitment (Voegel et al. 1998). In the case of ER, TR, GR, AR, and retinoid X receptor (RXR), preference for one of the three NR boxes on SRC-2 has been demonstrated; however, similar receptor-specificity has not been reported for the MR (Ding et al. 1998, Voegel et al. 1998). SRC-2 can enhance 
ligand-induced transactivation of both the AF-1 and AF-2 of MR (Fuse et al. 2000, Wang et al. 2004a). Similar transactivation of the MR has been demonstrated with GR interacting protein 1 (GRIP1), the mouse ortholog of human SRC-2 (Hong et al. 1997). Like CBP, GRIP1 has also been shown to enhance the $\mathrm{AR} \mathrm{N}-/ \mathrm{C}$-interaction, although a role in the $\mathrm{MR} \mathrm{N}-/ \mathrm{C}$-interaction has not been sought (Shen et al. 2005).

PPAR- $\gamma$ coactivator 1 (PGC-1) is another strong coactivator of the MR (Knutti et al. 2000). Originally discovered as a coactivator of PPAR- $\gamma$, it has been extensively studied in the context of mitochondrial biogenesis and oxidative metabolism (Puigserver et al. 1998, Knutti \& Kralli 2001). PGC-1 $\alpha$ is the best studied member of the PGC-1 family and possesses powerful coactivation capacity by simultaneously recruiting a histone acetyltransferase complex including SRC-1 and $\mathrm{CBP} / \mathrm{p} 300$ and facilitating the binding of the NR to the transcription initiation complex (Lin et al. 2005, Handschin \& Spiegelman 2006). It is expressed in a tissue-specific manner with predominance in metabolically active tissues such as the heart, skeletal muscle, brown fat, kidney, brain, and liver (Knutti et al. 2000, Handschin \& Spiegelman 2006). Tissue-specific activity has been demonstrated at different PPAR- $\gamma$ target gene promoters; similar studies have not been performed for the MR (Puigserver et al. 1998). PGC- $1 \alpha$ contains one NR box (LKKLL) and is able to significantly enhance hormone-dependent transcription mediated by MR via interaction with the AF-2 (Knutti et al. 2000). Ligand-specificity has not been demonstrated for the interaction between the MR LBD and PGC-1 $\alpha$ (Hultman et al. 2005), however, the LBD alone may not accurately reflect coregulator recruitment by the full-length MR. The physiological significance of PGC- $1 \alpha$ in MR-mediated transactivation is unclear, especially in the kidney, where PGC-1 is expressed predominantly in the proximal tubules and thick ascending loops of Henle (Portilla et al. 2002) while the MR is expressed in the distal convoluted tubules and cortical collecting ducts (Lombes et al. 1990).

It is important to note that NRs and coactivators can bind independently of the LXXLL motif, as has been demonstrated for SRC1e and TIF2/GRIP1. In the case of the MR, the AF-1 is poorly conserved and is therefore thought to recruit a unique set of non-LXXLL containing coregulators. One such coactivator is RNA helicase A (RHA; Kitagawa et al. 2002), which is a component of the RNA polymerase II complex that interacts with $\mathrm{CBP} / \mathrm{p} 300$ to stabilize complex formation (Nakajima et al. 1997). RHA has been shown to bind directly to MR AF-1a and enhance transcription when the RHA/CBP complex is recruited to full-length MR in the presence of aldosterone, but not cortisol (Kitagawa et al. 2002). This suggests aldosterone binding to MR may induce a conformational change that permits access by the RHA/CBP complex, while cortisol binding may induce a conformation that blocks RHA/CBP complex association, creating scope for ligand-specific actions at the MR. It may also be that the $\mathrm{N}-/ \mathrm{C}$-interaction, which is uniquely aldosterone induced (Rogerson \& Fuller 2003, Rogerson et al. 2004), is required for the RHA/CBP complex to bind the NTD.

The human elongation factor, 11-19 lysine-rich leukemia (ELL), named for its contribution to the pathogenesis of acute myeloid leukemia, is another AF-1 specific coactivator of the MR (Shilatifard et al. 2003, Pascual-Le Tallec et al. 2005). ELL is a RNA polymerase II elongation factor that increases polymerase II activity (Shilatifard 1998). ELL increases MR transcriptional activity and sensitivity to aldosterone and cortisol independently of total MR protein levels (Pascual-Le Tallec et al. 2005). The AF-1b region of the MR is crucial for ELL's potentiation of MR activity, while AF-1a, AF-2, and all five sumoylation sites are dispensable. By contrast, ELL markedly suppresses GR-mediated transactivation and has no effect on AR- or PR-mediated transactivation. ELL is co-expressed with the MR in the nuclei of cortical collecting duct cells of the human kidney, and is rapidly upregulated at physiological aldosterone concentrations, consistent with it being of physiological significance (Pascual-Le Tallec et al. 2005). Both ELL and RHA interact with RNA polymerase II, thus it may be postulated that they are recruited to different regions of the MR NTD as part of a complex that facilitates MR-mediated transactivation. Moreover, given RHA is capable of differentiating between aldosterone and cortisol and that ELL can differentiate between the MR and the GR, together, these coregulators may thus confer specificity to MR activity.

A number of other AF-1 interacting coregulators have been isolated by screening a human brain cDNA library, including death domain-associated protein (DAXX), FLICE-associated huge protein (FLASH), and Fasassociated factor 1 (FAF-1), factors implicated in cell apoptosis (Obradovic et al. 2004). While all three interact with both MR and GR, their effects are cell-context dependent. In a hippocampal cell line, FLASH increases the transactivation of MR and GR, FAF-1 specifically enhances MR-mediated transactivation with no effect on GR; and DAXX represses the transactivation of both MR and GR. By contrast, in a neuroblastoma cell line, the effects of FLASH and FAF-1 are attenuated while DAXX is able to differentially modulate MR- and GR-induced transactivation by potentiating or repressing their responses respectively. These proteins are expressed in the mouse hippocampus and may partly account for the different effects mediated by MR and GR in neuronal cells. However, their roles in other MR-expressing tissues are undefined. 
As previously mentioned, sumoylation is a posttranslational modification utilized by many NRs, including the MR (Tallec et al. 2003). It involves the covalent attachment of the ubiquitin-like protein SUMO-1 to its target and requires four enzymes: the SUMO protease, E1-activating enzyme, E2-conjugating enzyme, and E3 ligase (Seeler \& Dejean 2003). Ubc9 is an E2-conjugating enzyme that acts as a coactivator of MR by forming a complex with the MR NTD and SRC-1, but potentiates MR-mediated transcription independently of its E2 SUMO-1-conjugating enzyme activity (Yokota et al. 2007). Both the full-length MR and its NTD, but not the LBD, interact strongly with Ubc9 in an aldosterone-sensitive manner. SRC-1 binds Ubc9 and synergistically potentiates MR-mediated transcription. $\mathrm{Ubc} 9$ is specifically recruited to the response element of the human epithelial sodium channel gene promoter together with MR in the presence of aldosterone. Furthermore, endogenous MR, Ubc9 and SRC-1 can be co-localized in the collecting duct cell nuclei of the mouse kidney, supporting a physiological role of Ubc9 in MR transactivation together with SRC-1. Ubc9 has previously been observed to interact with the GR (Gottlicher et al. 1996) and the AR (Poukka et al. 1999), although in the AR, Ubc9 interacts with the nuclear localization signal to enhance testosteroneinduced transcription, also independently of its ability to conjugate SUMO-1. However, in these studies, the effect of ligand variability was not assessed, nor was the interaction of Ubc9 with other known coregulators. The spatio-temporal regulation of the dual roles of Ubc9, as SUMO E2 conjugating enzyme and NR coactivator, has yet to be determined.

As introduced earlier, splice variants of the MR may contribute to its ligand- or tissue-specific actions. hMR $\Delta 5,6$ lacks the entire receptor hinge region and the LBD (including AF-2) and has been shown to bind DNA and potentiate the transcriptional activation of wild-type hMR and hGR by recruitment of coactivators to its NTD (Zennaro et al. 2001). In particular, it was shown to recruit SRC-1 (both SRC1a and -1e), TIF1- $\alpha$ $(\mathrm{TIF} 1-\alpha)$ and receptor interacting protein 140 (RIP140). RIP140 increased transcriptional activation of hMR $\Delta 5,6$ despite weak binding. This is consistent with previous work demonstrating that RIP140 preferentially binds NRs via AF-2 rather than AF-1 (L'Horset et al. 1996). Of note, while TIF1- $\alpha$ interacts weakly with the MR AF-2 (Thenot et al. 1997), it is able to increase the transactivation of hMR $\Delta 5,6$ more than twofold and associate strongly with hMR $\Delta 5,6$ in a GST pull-down (Zennaro et al. 2001). hMR $\Delta$ 5,6 transcripts are present at different levels in many human tissues. It is plausible that differential tissue expression of hMR $\Delta 5,6$ and its unique coactivator recruitment profile forms another mechanism of tissue-specific MR modulation.

\section{Corepressors of the MR}

NCoR and SMRT are the first corepressors identified and have been shown to attenuate MR/aldosteronemediated transactivation (Wang et al. 2004a). While SMRT can induce a substantial down-regulation in aldosterone-mediated transactivation, NCoR has only a weak effect, which may reflect the experiment's choice of CV-1 cells that have high levels of endogenous NCoR. By contrast, an almost identical effect of NCoR and SMRT can be observed for the GR (Szapary et al. 1999).

DAXX is a transcriptional modulator that colocalizes with promyelocytic leukemia protein oncogenic domains in the nucleus, playing a role in Fas-linked cell apoptosis (Yang et al. 1997, Torii et al. 1999). As discussed earlier, it can repress MR and GR transactivation in a dose dependent manner in mouse hippocampus-derived cells (Obradovic et al. 2004). However, similar repression of MR and GR activity is not observed in human neuroblastoma cells, suggesting the importance of cellular environment for transcriptional silencing. DAXX mRNA transcripts are found in the rat hippocampus and are down-regulated in the absence of endogenous aldosterone and cortisol, suggesting that DAXX may play a physiological role in regulating MR and GR activity, at least in the rat brain.

Another corepressor of the MR is the protein inhibitor of activated STAT1 (PIAS1; Pascual-Le Tallec et al. 2003). PIAS1 is isolated from a human kidney library using both the MR NTD and its amino acid 163-437 fragments (i.e., the inhibitory domain between $\mathrm{AF}-1 \mathrm{a}$ and $\mathrm{AF}-1 \mathrm{~b})$ as bait. It significantly inhibits aldosterone-induced transactivation but does not affect basal MR activity in the absence of ligand. This suggests that a specific ligand-dependent conformational change in the LBD is required for PIAS1 to repress MR activity. In this particular study, the repressive effect of PIAS1 appears to be MR-specific as it has no effect on dexamethasone-induced GR transactivation. The exact mechanism behind the repressive action of PIAS1 is unclear, although it plays a role in SUMO modification as an E3 ligase (Jackson 2001, Rogers et al. 2003). Interestingly, while PIAS1 depends on sumoylation of the MR for its repressive effect at the GR response element promoter, its repression of MR activity is sumoylation-independent in the context of a murine mammary tumor virus promoter (Pascual-Le Tallec et al. 2003). This suggests that the repressive effect of PIAS1 is promoter-dependent and partially relies on SUMO modification. Moreover, PIAS1 has been shown to enhance the transcriptional activity of AR and GR while repressing that of PR (Tan et al. 2000, Gross et al. 2001). PIAS1 contains two overlapping CoRNR boxes, which are the common motifs found in corepressors, 
Table 1 Summary of coactivators that interact with the mineralocorticoid receptor (MR)

\begin{tabular}{|c|c|c|c|}
\hline & $\begin{array}{l}\text { Site of interaction } \\
\text { with the MR }\end{array}$ & Functions of the coactivator & References relevant to the MR \\
\hline \multicolumn{4}{|l|}{ Coactivator } \\
\hline $\begin{array}{l}\text { SRC-2, TIF2, } \\
\text { GRIP1 } \\
\text { (mouse ortholog) }\end{array}$ & AF-1, AF-2 & Enhances transactivation & $\begin{array}{l}\text { Hong et al. (1997), Fuse et al. (2000) } \\
\text { and Wang et al. (2004a) }\end{array}$ \\
\hline PGC-1 $\alpha$ & AF-2 & $\begin{array}{l}\text { Recruits histone acetyltransferase complex; } \\
\text { facilitates binding of NR to transcription initiation } \\
\text { complex }\end{array}$ & $\begin{array}{l}\text { Knutti et al. (2000) and Hultman } \\
\text { et al. (2005) }\end{array}$ \\
\hline $\mathrm{RHA}$ & AF-1a & $\begin{array}{l}\text { Component of RNA polymerase II complex; } \\
\text { recruits CBP }\end{array}$ & Kitagawa et al. (2002) \\
\hline FAF-1 & $A F-1$ & Regulates cell apoptosis & Obradovic et al. (2004) \\
\hline Ubc9 & NTD & $\begin{array}{l}\text { SUMO E2-conjugating enzyme; forms } \\
\text { coactivation complex with SRC-1 }\end{array}$ & Yokota et al. (2007) \\
\hline TIF1- $\alpha$ & NTD & Transcriptional coactivator & Zennaro et al. (2001) \\
\hline RIP140 & NTD & NR coactivator & Zennaro et al. (2001) \\
\hline
\end{tabular}

however, this region is not responsible for its repression of MR activity as a PIAS1 mutant lacking the CoRNR boxes is still able to inhibit MR-mediated transactivation (Tallec et al. 2003).

More recently, NF-YC has been reported to be a corepressor of the MR via interaction with AF-1 (Shibata et al. 2008). Overexpression of NF-YC inhibits MR transcriptional activity while depletion of endogenous NF-YC increases MR transcription in an aldosteronedependent fashion. NF-Y is a ubiquitous heterotrimeric transcription factor, composed of NF-YA, NF-YB, and NF-YC subunits, which recognizes a CCAAT box motif found in many eukaryotic promoter and enhancer elements (Nakshatri et al. 1996). The exact mechanism of its interaction with the MR remains to be elucidated.

\section{Other searches for MR coregulators}

The number of MR-interacting coregulators identified to date is limited to only 11 coactivators and 5 corepressors (see Tables 1 and 2). To screen for more MR coregulators, Hultman et al. (2005) used a mammalian two-hybrid assay to analyze 50 coregulator peptides that contain either the LXXLL or I/L-XX-I/ V-I motifs, derived from 23 known coactivators and corepressors. Surprisingly, only peptides from SRC-1, activating signal cointegrator 2 (ASC2) and PGC1- $\alpha$ showed strong ligand-dependent interactions with the MR LBD. Full-length ASC2 is known to potentiate transactivation mediated by the RXR, RAR, TR, ER- $\alpha$, and GR, but has not been previously evaluated for the MR (Lee et al. 1999). In a very similar study,

Table 2 Summary of corepressors that interact with the mineralocorticoid receptor (MR)

Sites of interaction with the MR

\section{Corepressor}

$\begin{array}{ll}\text { SMRT } & \text { LBD } \\ \text { NCoR } & \text { LBD } \\ \text { DAXX } & \text { NTD } \\ \text { PIAS1 } & \text { NTD } \pm \text { LBD }\end{array}$

NF-YC

\section{Functions of the corepressors}

Histone deacetylase
Histone deacetylase
Regulates cell apoptosis; represses MR
transactivation in some cell lines
SUMO E3 ligase; exact mechanism of
repressive action unclear
Unknown

\section{Reference relevant to the MR}

Wang et al. (2004a)

Wang et al. (2004a)

Obradovic et al. (2004)

Pascual-Le Tallec et al. (2003)

Shibata et al. (2008) 
Li et al. (2005) screened 38 peptides in an $\alpha$ screen for competitive binding to ligand-bound MR against an LXXLL motif from SRC-2. They found that only six peptides derived from DAX1, SRC-1, SRC-2, SRC-3, PGC1- $\alpha$ and PGC1- $\beta$ bound MR strongly. Both of these studies also demonstrated that the peptide binding profile was identical for aldosterone, cortisol, and corticosterone, although it should be noted that the MR LBD was used as bait rather than a full-length MR and only LXXLL-containing peptides were tested. It is plausible that motifs other than LXXLL may be important for ligand-specific interactions with the MR. Furthermore, the NTD of the MR neither contain an LXXLL motif, nor the F/WXXLL motif shown to be critical for the $\mathrm{N}-/ \mathrm{C}$ - interaction in the $\mathrm{AR}$, yet it participates in an $\mathrm{N}-/ \mathrm{C}$ - interaction with the LBD.

\section{Coregulators in disease and treatment}

Alterations in coregulator expression have been linked to a number of pathologies, in particular hormoneresponsive cancers such as breast and prostate cancer. In the case of breast cancer, a few studies have found elevated levels of steroid receptor RNA activator and amplified in breast cancer-1 (AIB1, also known as SRC-3), suggesting that raised coactivator levels may increase tumor sensitivity to estrogen and growth factors (Anzick et al. 1997, Leygue et al. 1999, Murphy et al. 2000, Bouras et al. 2001). SERMs such as tamoxifen have been effective in combating ER positive breast cancers without inducing ER antagonism in bone, in part due to their effect on tissue-specific coactivators (Hall \& McDonnell 2005). In the case of prostate cancer, the loss of sirtuin 1 (SIRT 1), a histone deacetylase required for AR antagonist-mediated transcriptional repression, or the overexpression of coactivators, is postulated to play a role in the development of AR-independent disease (Dai et al. 2007). These coregulators are actively targeted in experimental therapy for anti-AR refractory prostate cancer (Heemers \& Tindall 2007).

It is now recognized that coregulators play an important role in a range of diseases including cancer, inflammatory disease, and metabolic disorders. Out of the 102 coregulators characterized in relation to disease, the following known MR coregulators are included: ELL in leukemia, PGC- $1 \alpha$ in the metabolic syndrome, PIAS1 in prostate cancer, SRC-1 in prostate, breast and gastric cancers, and Ubc9 in melanoma, ovarian, and lung cancers (Lonard et al. 2007). None of these diseases are distinctively MR driven. However, given the crucial role of coregulators in MR function, changes in coregulator expression may be implicated in pathology associated with aberrant
MR activation such as cardiac fibrosis and heart failure (Costello-Boerrigter et al. 2007, Funder 2007, Young et al. 2007, Shapiro et al. 2008).

\section{Conclusion and future directions}

Over the last decade, it has become clear that coregulators are important in mediating the diverse and complex actions of NRs. In contrast to other NRs, especially the AR which has over 160 potential coregulators (Heemers \& Tindall 2007), the MR has been demonstrated to interact with only a limited number, although it seems probable that more interacting partners exist for the MR. Future studies focused on identifying more coregulators which interact specifically with the MR will provide insights into important molecular signaling pathways for MR action. Given the observed differences in coregulator binding between full-length ER and ER LBD, it would be desirable to screen for coregulators in the context of the full-length MR bound by different ligands, using techniques such as peptide phage display, yeast two-hybrid assays or biochemical purification of MR-interacting protein complexes. Furthermore, regulation of tissue levels of coregulators in MR-mediated disease will also be informative. The discovery of tissue- or ligand-specific coregulators should facilitate the development of selective MR modulators which can confer desirable tissue-specific effects while retaining normal MR function in other tissues.

\section{Declaration of interest}

Jun Yang has nothing to declare. Morag J Young has been the recipient of previous research grants from Pfizer and Merck; the present review does not relate to these activities.

\section{Funding}

This work is supported by the National Health and Medical Research Council of Australia (grants 494835 and 494811) in addition to a Shields Research Entry Scholarship from the Royal Australasian College of Physicians.

\section{Acknowledgements}

The authors are grateful to Professor Peter J Fuller and Dr Colin D Clyne for critically reading the manuscript and Ms Sue Panckridge for assistance with preparing the tables and diagrams.

\section{References}

Alnemri ES, Maksymowych AB, Robertson NM \& Litwack G 1991 Overexpression and characterization of the human mineralocorticoid receptor. Journal of Biological Chemistry 266 18072-18081. 
Alzamora R, Michea L \& Marusic ET 2000 Role of 11\{beta\}hydroxysteroid dehydrogenase in nongenomic aldosterone effects in human arteries. Hypertension 35 1099-1104.

Anzick SL, Kononen J, Walker RL, Azorsa DO, Tanner MM, Guan XY, Sauter G, Kallioniemi OP, Trent JM \& Meltzer PS 1997 AIB1, a steroid receptor coactivator amplified in breast and ovarian cancer. Science 277 965-968.

Auboeuf D, Honig A, Berget SM \& O'Malley BW 2002 Coordinate regulation of transcription and splicing by steroid receptor coregulators. Science 298 416-419.

Baker ME, Chandsawangbhuwana C \& Ollikainen N 2007 Structural analysis of the evolution of steroid specificity in the mineralocorticoid and glucocorticoid receptors. BMC Evolutionary Biology 724.

Bledsoe RK, Madauss KP, Holt JA, Apolito CJ, Lambert MH, Pearce KH, Stanley TB, Stewart EL, Trump RP, Willson TM et al. 2005 A ligand-mediated hydrogen bond network required for the activation of the mineralocorticoid receptor. Journal of Biological Chemistry 280 31283-31293.

Bocchi B, Fagart J, Cluzeaud F, Fay M, Rafestin-Oblin M-E \& Farman N 2003 Glucocorticoid metabolism by 11-beta hydroxysteroid dehydrogenase type 2 modulates human mineralocorticoid receptor transactivation activity. Journal of Steroid Biochemistry and Molecular Biology 84 239-244.

Bookout AL, Jeong Y, Downes M, Yu RT, Evans RM \& Mangelsdorf DJ 2006 Anatomical profiling of nuclear receptor expression reveals a hierarchical transcriptional network. Cell 126 789-799.

Bouras T, Southey MC \& Venter DJ 2001 Overexpression of the steroid receptor coactivator AIB1 in breast cancer correlates with the absence of estrogen and progesterone receptors and positivity for p53 and HER2/neu. Cancer Research 61 903-907.

Caprio M, Feve B, Claes A, Viengchareun S, Lombes M \& Zennaro M-C 2007 Pivotal role of the mineralocorticoid receptor in corticosteroidinduced adipogenesis. FASEB Journal 21 2185-2194.

Centenera MM, Harris JM, Tilley WD \& Butler LM 2008 The contribution of different androgen receptor domains to receptor dimerization and signaling. Molecular Endocrinology 22 2373-2382.

Chang C-Y \& McDonnell DP 2005 Androgen receptor-cofactor interactions as targets for new drug discovery. Trends in Pharmacological Sciences 26 225-228.

Chang C-Y, Norris JD, Gron H, Paige LA, Hamilton PT, Kenan DJ, Fowlkes D \& McDonnell DP 1999 Dissection of the LXXLL nuclear receptor-coactivator interaction motif using combinatorial peptide libraries: discovery of peptide antagonists of estrogen receptors alpha and beta. Molecular and Cellular Biology 19 8226-8239.

Chang C-Y, Abdo J, Hartney T \& McDonnell DP 2005 Development of peptide antagonists for the androgen receptor using combinatorial peptide phage display. Molecular Endocrinology 19 2478-2490.

Chen JD \& Evans RM 1995 A transcriptional co-repressor that interacts with nuclear hormone receptors. Nature 377 454-457.

Christy C, Hadoke PW, Paterson JM, Mullins JJ, Seckl JR \& Walker BR 200311 \{beta\}-Hydroxysteroid dehydrogenase type 2 in mouse aorta: localization and influence on response to glucocorticoids. Hypertension 42 580-587.

Clyne CD, Chang C-Y, Safi R, Fuller PJ, McDonnell DP \& Young MJ 2009 Purification and characterization of recombinant human mineralocorticoid receptor. Molecular and Cellular Endocrinology 302 $81-85$.

Costello-Boerrigter LC, Boerrigter G, Harty GJ, Cataliotti A, Redfield MM \& Burnett JC Jr 2007 Mineralocorticoid escape by the kidney but not the heart in experimental asymptomatic left ventricular dysfunction. Hypertension 50 481-488.

Dai Y, Ngo D, Forman LW, Qin DC, Jacob J \& Faller DV 2007 Sirtuin 1 is required for antagonist-induced transcriptional repression of androgen-responsive genes by the androgen receptor. Molecular Endocrinology 21 1807-1821.
Darimont BD, Wagner RL, Apriletti JW, Stallcup MR, Kushner PJ, Baxter JD, Fletterick RJ \& Yamamoto KR 1998 Structure and specificity of nuclear receptor-coactivator interactions. Genes and Development 12 3343-3356.

Ding XF, Anderson CM, Ma H, Hong H, Uht RM, Kushner PJ \& Stallcup MR 1998 Nuclear receptor-binding sites of coactivators glucocorticoid receptor interacting protein 1 (GRIP1) and steroid receptor coactivator 1 (SRC-1): multiple motifs with different binding specificities. Molecular Endocrinology 12 302-313.

Edwards CR, Stewart PM, Burt D, Brett L, McIntyre MA, Sutanto WS, de Kloet ER \& Monder C 1988 Localisation of 11 betahydroxysteroid dehydrogenase-tissue specific protector of the mineralocorticoid receptor. Lancet 2 986-989.

Fagart J, Wurtz JM, Souque A, Hellal-Levy C, Moras D \& Rafestin-Oblin ME 1998 Antagonism in the human mineralocorticoid receptor. EMBO Journal 17 3317-3325.

Fagart J, Huyet J, Pinon GM, Rochel M, Mayer C \& Rafestin-Oblin M-E 2005 Crystal structure of a mutant mineralocorticoid receptor responsible for hypertension. Nature Structural and Molecular Biology $12554-555$.

Farman N \& Rafestin-Oblin ME 2001 Multiple aspects of mineralocorticoid selectivity. American Journal of Physiology. Renal Physiology 280 F181-F192.

Funder JW 2005 The nongenomic actions of aldosterone. Endocrine Reviews 26 313-321.

Funder JW 2007 The role of aldosterone and mineralocorticoid receptors in cardiovascular disease. American Journal of Cardiovascular Drugs 7 151-157.

Funder JW, Pearce PT, Smith R \& Smith AI 1988 Mineralocorticoid action: target tissue specificity is enzyme, not receptor, mediated. Science 242 583-585.

Fuse H, Kitagawa H \& Kato S 2000 Characterization of transactivational property and coactivator mediation of rat mineralocorticoid receptor activation function-1 (AF-1). Molecular Endocrinology 14 889-899.

Galigniana MD, Piwien Pilipuk G, Kanelakis KC, Burton G \& Lantos CP 2004 Molecular mechanism of activation and nuclear translocation of the mineralocorticoid receptor upon binding of pregnanesteroids. Molecular and Cellular Endocrinology 217 167-179.

Geller DS, Farhi A, Pinkerton N, Fradley M, Moritz M, Spitzer A, Meinke G, Tsai FTF, Sigler PB \& Lifton RP 2000 Activating mineralocorticoid receptor mutation in hypertension exacerbated by pregnancy. Science 289 119-123.

Gomez-Sanchez CE, de Rodriguez AF, Romero DG, Estess J, Warden MP, Gomez-Sanchez MT \& Gomez-Sanchez EP 2006 Development of a panel of monoclonal antibodies against the mineralocorticoid receptor. Endocrinology 147 1343-1348.

Goodson M, Jonas BA \& Privalsky MA 2005 Corepressors: custom tailoring and alterations while you wait. Nuclear Receptor Signaling 3 e003.

Gottlicher M, Heck S, Doucas V, Wade E, Kullmann M, Cato AC, Evans RM \& Herrlich P 1996 Interaction of the Ubc9 human homologue with c-Jun and with the glucocorticoid receptor. Steroids 61 257-262.

Govindan MV \& Warriar N 1998 Reconstitution of the N-terminal transcription activation function of human mineralocorticoid receptor in a defective human glucocorticoid receptor. Journal of Biological Chemistry 273 24439-24447.

Gross M, Liu B, Tan J, French FS, Carey M \& Shuai K 2001 Distinct effects of PIAS proteins on androgen-mediated gene activation in prostate cancer cells. Oncogene 20 3880-3887.

Hall JM \& McDonnell DP 2005 Coregulators in nuclear estrogen receptor action: from concept to therapeutic targeting. Molecular Interventions 5 343-357.

Handschin C \& Spiegelman BM 2006 Peroxisome proliferatoractivated receptor gamma coactivator 1 coactivators, energy homeostasis, and metabolism. Endocrine Reviews 27 728-735. 
He B, Kemppainen JA \& Wilson EM 2000 FXXLF and WXXLF sequences mediate the NH2-terminal interaction with the ligand binding domain of the androgen receptor. Journal of Biological Chemistry 275 22986-22994.

Heemers HV \& Tindall DJ 2007 Androgen receptor (AR) coregulators: a diversity of functions converging on and regulating the AR transcriptional complex. Endocrine Reviews 28 778-808.

Heery DM, Kalkhoven E, Hoare S \& Parker MG 1997 A signature motif in transcriptional co-activators mediates binding to nuclear receptors. Nature 387 733-736.

Hellal-Levy C, Fagart J, Souque A \& Rafestin-Oblin ME $2000 a$ Mechanistic aspects of mineralocorticoid receptor activation. Kidney International 57 1250-1255.

Hellal-Levy C, Fagart J, Souque A, Wurtz JM, Moras D \& Rafestin-Oblin ME $2000 b$ Crucial role of the H11-H12 loop in stabilizing the active conformation of the human mineralocorticoid receptor. Molecular Endocrinology 14 1210-1221.

Hong H, Kohli K, Garabedian MJ \& Stallcup MR 1997 GRIP1, a transcriptional coactivator for the AF-2 transactivation domain of steroid, thyroid, retinoid, and vitamin D receptors. Molecular and Cellular Biology 17 2735-2744.

Horlein AJ, Naar AM, Heinzel T, Torchia J, Gloss B, Kurokawa R, Ryan A, Kamei Y, Soderstrom M, Glass CK et al. 1995 Ligandindependent repression by the thyroid hormone receptor mediated by a nuclear receptor co-repressor. Nature 377 397-404.

Hu X \& Lazar MA 1999 The CoRNR motif controls the recruitment of corepressors by nuclear hormone receptors. Nature 402 93-96.

Hultman ML, Krasnoperova NV, Li S, Du S, Xia C, Dietz JD, Lala DS, Welsch DJ \& Hu X 2005 The ligand-dependent interaction of mineralocorticoid receptor with coactivator and corepressor peptides suggests multiple activation mechanisms. Molecular Endocrinology 19 1460-1473.

Ikonen T, Palvimo JJ \& Janne OA 1997 Interaction between the amino- and carboxyl-terminal regions of the rat androgen receptor modulates transcriptional activity and is influenced by nuclear receptor coactivators. Journal of Biological Chemistry 272 29821-29828.

Jackson PK 2001 A new RING for SUMO: wrestling transcriptional responses into nuclear bodies with PIAS family E3 SUMO ligases. Genes and Development 15 3053-3058.

Juurlink DN, Mamdani MM, Lee DS, Kopp A, Austin PC, Laupacis A \& Redelmeier DA 2004 Rates of hyperkalemia after publication of the randomized aldactone evaluation study. New England Journal of Medicine 351 543-551.

Kitagawa H, Yanagisawa J, Fuse H, Ogawa S, Yogiashi Y, Okuno A, Nagasawa H, Nakajima T, Matsumoto T \& Kato S 2002 Ligandselective potentiation of rat mineralocorticoid receptor activation function 1 by a CBP-containing histone acetyltransferase complex. Molecular and Cellular Biology 22 3698-3706.

de Kloet ER, Joels M \& Holsboer F 2005 Stress and the brain: from adaptation to disease. Nature Reviews. Neuroscience 6 463-475.

Knutti D \& Kralli A 2001 PGC-1, a versatile coactivator. Trends in Endocrinology and Metabolism 12 360-365.

Knutti D, Kaul A \& Kralli A 2000 A tissue-specific coactivator of steroid receptors, identified in a functional genetic screen. Molecular and Cellular Biology 20 2411-2422.

Ko L, Cardona GR, Henrion-Caude A \& Chin WW 2002 Identification and characterization of a tissue-specific coactivator, GT198, that interacts with the DNA-binding domains of nuclear receptors. Molecular and Cellular Biology 22 357-369.

van der Laan S \& Meijer OC 2008 Pharmacology of glucocorticoids: beyond receptors. European Journal of Pharmacology 585 483-491.

Lavery DN \& McEwan IJ 2005 Structure and function of steroid receptor $\mathrm{AF} 1$ transactivation domains: induction of active conformations. Biochemical Journal 391 449-464.

Lee S-K, Anzick SL, Choi J-E, Bubendorf L, Guan X-Y, Jung Y-K, Kallioniemi OP, Kononen J, Trent JM, Azorsa D et al. 1999 A nuclear factor, ASC-2, as a cancer-amplified transcriptional coactivator essential for ligand-dependent transactivation by nuclear receptors in vivo. Journal of Biological Chemistry 274 34283-34293.

Leygue E, Dotzlaw H, Watson PH \& Murphy LC 1999 Expression of the steroid receptor RNA activator in human breast tumors. Cancer Research 59 4190-4193.

L'Horset F, Dauvois S, Heery DM, Cavailles V \& Parker MG 1996 RIP-140 interacts with multiple nuclear receptors by means of two distinct sites. Molecular and Cellular Biology 16 6029-6036.

Li Y, Suino K, Daugherty J \& Xu HE 2005 Structural and biochemical mechanisms for the specificity of hormone binding and coactivator assembly by mineralocorticoid receptor. Molecular Cell 19 367-380.

Li J, Fu J, Toumazou C, Yoon H-G \& Wong J 2006 A role of the amino-terminal $(\mathrm{N})$ and carboxyl-terminal $(\mathrm{C})$ interaction in binding of androgen receptor to chromatin. Molecular Endocrinology 20 776-785.

Lin J, Handschin C \& Spiegelman BM 2005 Metabolic control through the PGC-1 family of transcription coactivators. Cell Metabolism 1 361-370.

Lombes M, Farman N, Oblin ME, Baulieu EE, Bonvalet JP, Erlanger BF \& Gasc JM 1990 Immunohistochemical localization of renal mineralocorticoid receptor by using an anti-idiotypic antibody that is an internal image of aldosterone. PNAS 87 1086-1088.

Lombes M, Oblin ME, Gasc JM, Baulieu EE, Farman N \& Bonvalet JP 1992 Immunohistochemical and biochemical evidence for a cardiovascular mineralocorticoid receptor. Circulation Research 71 503-510.

Lombes M, Binart N, Delahaye F, Baulieu EE \& Rafestin-Oblin ME $1994 a$ Differential intracellular localization of human mineralocorticosteroid receptor on binding of agonists and antagonists. Biochemical Journal 302 191-197.

Lombes M, Kenouch S, Souque A, Farman N \& Rafestin-Oblin ME $1994 b$ The mineralocorticoid receptor discriminates aldosterone from glucocorticoids independently of the 11 beta-hydroxysteroid dehydrogenase. Endocrinology 135 834-840.

Lombes M, Farman N, Bonvalet JP \& Zennaro MC 2000 Identification and role of aldosterone receptors in the cardiovascular system. Annales d'Endocrinologie 61 41-46.

Lonard DM 2007 Nuclear receptor coregulators: judges, juries, and executioners of cellular regulation. Molecular Cell 27 691-700.

Lonard DM \& O'Malley BW 2006 The expanding cosmos of nuclear receptor coactivators. Cell 125 411-414.

Lonard DM, Lanz RB \& O'Malley BW 2007 Nuclear receptor coregulators and human disease. Endocrine Reviews 28 575-587.

Losel R \& Wehling M 2003 Nongenomic actions of steroid hormones. Nature Reviews Molecular Cell Biology 4 46-56.

McEwan IJ, Lavery D, Fischer K \& Watt K 2007 Natural disordered sequences in the amino terminal domain of nuclear receptors: lessons from the androgen and glucocorticoid receptors. Nuclear Receptor Signaling 5 e001.

McInerney EM, Rose DW, Flynn SE, Westin S, Mullen TM, Krones A, Inostroza J, Torchia J, Nolte RT, Assa-Munt N et al. 1998 Determinants of coactivator LXXLL motif specificity in nuclear receptor transcriptional activation. Genes and Development 12 $3357-3368$.

McKenna NJ \& O'Malley BW 2000 From ligand to response: generating diversity in nuclear receptor coregulator function. Journal of Steroid Biochemistry and Molecular Biology 74 351-356.

Meijer OC 2002 Coregulator proteins and corticosteroid action in the brain. Journal of Neuroendocrinology 14 499-505.

Meijer OC, Kalkhoven E, van der Laan S, Steenbergen PJ, Houtman SH, Dijkmans TF, Pearce D \& de Kloet ER 2005 Steroid receptor coactivator-1 splice variants differentially affect corticosteroid receptor signaling. Endocrinology 146 1438-1448.

Metivier R, Penot G, Hubner MR, Reid G, Brand H, Kos M \& Gannon F 2003 Estrogen receptor-alpha directs ordered, cyclical, and combinatorial recruitment of cofactors on a natural target promoter. Cell 115 751-763. 
Mihailidou AS, Mardini M \& Funder JW 2004 Rapid, Nongenomic effects of aldosterone in the heart mediated by \{epsilon\} protein kinase C. Endocrinology 145 773-780.

Murphy LC, Simon SL, Parkes A, Leygue E, Dotzlaw H, Snell L, Troup S, Adeyinka A \& Watson PH 2000 Altered expression of estrogen receptor coregulators during human breast tumorigenesis. Cancer Research 60 6266-6271.

Nakajima T, Uchida C, Anderson SF, Lee CG, Hurwitz J, Parvin JD \& Montminy M 1997 RNA helicase A mediates association of CBP with RNA polymerase II. Cell 90 1107-1112.

Nakshatri H, Bhat-Nakshatri P \& Currie RA 1996 Subunit association and DNA binding activity of the heterotrimeric transcription factor NF-Y is regulated by cellular redox. Journal of Biological Chemistry 271 28784-28791.

Obradovic D, Tirard M, Nemethy Z, Hirsch O, Gronemeyer H \& Almeida OFX 2004 DAXX, FLASH, and FAF-1 modulate mineralocorticoid and glucocorticoid receptor-mediated transcription in hippocampal cells: toward a basis for the opposite actions elicited by two nuclear receptors? Molecular Pharmacology 65 761-769.

Ogryzko VV, Schiltz RL, Russanova V, Howard BH \& Nakatani Y 1996 The transcriptional coactivators p300 and CBP are histone acetyltransferases. Cell 87 953-959.

O'Malley BW 2007 Coregulators: from whence came these 'master genes'. Molecular Endocrinology 21 1009-1013.

Onate SA, Tsai SY, Tsai M-J \& O'Malley BW 1995 Sequence and characterization of a coactivator for the steroid hormone receptor superfamily. Science v270 1354.

Ortlund EA, Bridgham JT, Redinbo MR \& Thornton JW 2007 Crystal structure of an ancient protein: evolution by conformational epistasis. Science 317 1544-1548.

Pascual-Le Tallec L, Kirsh O, Lecomte M-C, Viengchareun S, Zennaro M-C, Dejean A \& Lombes M 2003 Protein inhibitor of activated signal transducer and activator of transcription 1 interacts with the N-terminal domain of mineralocorticoid receptor and represses its transcriptional activity: implication of small ubiquitin-related modifier 1 modification. Molecular Endocrinology 17 2529-2542.

Pascual- Le Tallec L, Simone F, Viengchareun S, Meduri G, Thirman MJ \& Lombes M 2005 The elongation factor ELL (eleven-nineteen lysine-rich leukemia) is a selective coregulator for steroid receptor functions. Molecular Endocrinology 19 1158-1169.

Pearce D, Bhargava A \& Cole TJ 2003 Aldosterone: its receptor, target genes, and actions. Vitamins and Hormone 66 29-76.

Perissi V, Aggarwal A, Glass CK, Rose DW \& Rosenfeld MG 2004 A corepressor/coactivator exchange complex required for transcriptional activation by nuclear receptors and other regulated transcription factors. Cell 116 511-526.

Pippal J \& Fuller P 2008 Structure-function relationships in the mineralocorticoid receptor. Journal of Molecular Endocrinology 41 405-413.

Pitt B, Zannad F, Remme WJ, Cody R, Castaigne A, Perez A, Palensky J Wittes J \& The Randomized Aldactone Evaluation Study I 1999 The effect of spironolactone on morbidity and mortality in patients with severe heart failure. New England Journal of Medicine 341 709-717.

Pitt B, Remme W, Zannad F, Neaton J, Martinez F, Roniker B, Bittman R, Hurley S, Kleiman J, Gatlin M et al. 2003 Eplerenone, a selective aldosterone blocker, in patients with left ventricular dysfunction after myocardial infarction. New England Journal of Medicine 348 1309-1321.

Portilla D, Dai G, McClure T, Bates L, Kurten R, Megyesi J, Price P \& Li S 2002 Alterations of PPAR[agr] and its coactivator PGC-1 in cisplatin-induced acute renal failure. Kidney International 62 1208-1218.

Poukka H, Aarnisalo P, Karvonen U, Palvimo JJ \& Janne OA 1999 Ubc9 interacts with the androgen receptor and activates receptordependent transcription. Journal of Biological Chemistry $\mathbf{2 7 4}$ 19441-19446.
Puigserver P, Wu Z, Park CW, Graves R, Wright M \& Spiegelman BM 1998 A cold-inducible coactivator of nuclear receptors linked to adaptive thermogenesis. Cell 92 829-839.

Rogers RS, Horvath CM \& Matunis MJ 2003 SUMO modification of STAT1 and its role in PIAS-mediated inhibition of gene activation. Journal of Biological Chemistry 278 30091-30097.

Rogerson FM \& Fuller PJ 2003 Interdomain interactions in the mineralocorticoid receptor. Molecular and Cellular Endocrinology 200 $45-55$.

Rogerson FM, Brennan FE \& Fuller PJ 2003 Dissecting mineralocorticoid receptor structure and function. Journal of Steroid Biochemistry and Molecular Biology 85 389-396.

Rogerson FM, Yao Y, Smith BJ \& Fuller PJ 2004 Differences in the determinants of eplerenone, spironolactone and aldosterone binding to the mineralocorticoid receptor. Clinical and Experimental Pharmacology and Physiology 31 704-709.

Rowan BG \& O'Malley BW 2000 Progesterone receptor coactivators. Steroids 65 545-549.

Seeler J-S \& Dejean A 2003 Nuclear and unclear functions of SUMO. Nature Reviews. Molecular Cell Biology 4 690-699.

Shang Y \& Brown M 2002 Molecular determinants for the tissue specificity of SERMs. Science 295 2465-2468.

Shapiro BP, Owan TE, Mohammed S, Kruger M, Linke WA, Burnett JC Jr \& Redfield MM 2008 Mineralocorticoid signaling in transition to heart failure with normal ejection fraction. Hypertension $\mathbf{5 1}$ 289-295.

Shen HC, Buchanan G, Butler LM, Prescott J, Henderson M, Tilley WD \& Coetzee GA 2005 GRIP1 mediates the interaction between the amino- and carboxyl-termini of the androgen receptor. Biological Chemistry 386 69-74.

Shibata H, Murai-Takeda A, Yokota K, Kurihara I, Kobayashi S, Mitsubishi Y, Kitagawa H, Kato S, Saruta T \& Itoh H. 2008 A repressive role for NF-YC in aldosterone signalling. Keystone Symposia on Molecular and Cellular Biology. Abstract Book, Whistler. 170.

Shilatifard A 1998 Factors regulating the transcriptional elongation activity of RNA polymerase II. FASEB Journal 12 1437-1446.

Shilatifard A, Conaway RC \& Conaway JW 2003 The RNA polymerase II elongation complex. Annual Review of Biochemistry 72 693-715.

Smith CL \& O'Malley BW 2004 Coregulator function: a key to understanding tissue specificity of selective receptor modulators. Endocrine Reviews 25 45-71.

Spencer TE, Jenster G, Burcin MM, Allis CD, Zhou J, Mizzen CA, McKenna NJ, Onate SA, Tsai SY, Tsai MJ et al. 1997 Steroid receptor coactivator-1 is a histone acetyltransferase. Nature $\mathbf{3 8 9}$ 194-198.

Sugiyama T, Yoshimoto T, Tsuchiya K, Gochou N, Hirono Y, Tateno T, Fukai N \& Shichiri M 2005 Aldosterone induces angiotensin converting enzyme gene expression via a JAK2-dependent pathway in rat endothelial cells. Endocrinology 146 3900-3906.

Sutanto W \& de Kloet KR 1991 Mineralocorticoid receptor ligands: biochemical, pharmacological, and clinical aspects. Medicinal Research Reviews 11 617-639.

Szapary D, Huang Y \& Simons SS Jr 1999 Opposing effects of corepressor and coactivators in determining the dose-response curve of agonists, and residual agonist activity of antagonists, for glucocorticoid receptor-regulated gene expression. Molecular Endocrinology 13 2108-2121.

Tallec LP-L \& Lombes M 2005 The mineralocorticoid receptor: a journey exploring its diversity and specificity of action. Molecular Endocrinology 19 2211-2221.

Tallec LP-L, Kirsh O, Lecomte M-C, Viengchareun S, Zennaro M-C, Dejean A \& Lombes M 2003 Protein inhibitor of activated signal transducer and activator of transcription 1 interacts with the N-terminal domain of mineralocorticoid receptor and represses its transcriptional activity: implication of small ubiquitinrelated modifier 1 modification. Molecular Endocrinology 17 2529-2542. 
Tan J, Hall SH, Hamil KG, Grossman G, Petrusz P, Liao J, Shuai K \& French FS 2000 Protein inhibitor of activated STAT-1 (signal transducer and activator of transcription-1) is a nuclear receptor coregulator expressed in human testis. Molecular Endocrinology 14 14-26.

Thenot S, Henriquet C, Rochefort H \& Cavailles V 1997 Differential interaction of nuclear receptors with the putative human transcriptional coactivator hTIF1. Journal of Biological Chemistry 272 12062-12068.

Torii S, Egan DA, Evans RA \& Reed JC 1999 Human Daxx regulates Fas-induced apoptosis from nuclear PML oncogenic domains (PODs). EMBO Journal 18 6037-6049.

Voegel JJ, Heine MJ, Zechel C, Chambon P \& Gronemeyer H 1996 TIF2, a $160 \mathrm{kDa}$ transcriptional mediator for the ligand-dependent activation function AF-2 of nuclear receptors. EMBO Journal $\mathbf{1 5}$ $3667-3675$.

Voegel JJ, Heine MJ, Tini M, Vivat V, Chambon P \& Gronemeyer H 1998 The coactivator TIF2 contains three nuclear receptorbinding motifs and mediates transactivation through CBP binding-dependent and -independent pathways. EMBO Journal 17 507-519.

Wang Q, Anzick S, Richter WF, Meltzer P \& Simons SS Jr 2004a Modulation of transcriptional sensitivity of mineralocorticoid and estrogen receptors. Journal of Steroid Biochemistry and Molecular Biology 91 197-210.

Wang Q, Blackford JA Jr, Song L-N, Huang Y, Cho S \& Simons SS Jr $2004 b$ Equilibrium interactions of corepressors and coactivators with agonist and antagonist complexes of glucocorticoid receptors. Molecular Endocrinology 18 1376-1395.

Warnmark A, Treuter E, Wright APH \& Gustafsson J-A 2003 Activation functions 1 and 2 of nuclear receptors: molecular strategies for transcriptional activation. Molecular Endocrinology 17 1901-1909.

Wurtz JM, Bourguet W, Renaud JP, Vivat V, Chambon P, Moras D \& Gronemeyer H 1996 A canonical structure for the ligand-binding domain of nuclear receptors. Nature Structural Biology 3206.
Xu J \& Li Q 2003 Review of the in vivo functions of the p160 steroid receptor coactivator family. Molecular Endocrinology 17 1681-1692.

Yang X, Khosravi-Far R, Chang HY \& Baltimore D 1997 Daxx, a novel Fas-binding protein that activates JNK and apoptosis. Cell 89 1067-1076.

Yokota K, Shibata H, Kurihara I, Kobayashi S, Suda N, Murai-Takeda A, Saito I, Kitagawa H, Kato S, Saruta T et al. 2007 Coactivation of the $\mathrm{N}$-terminal transactivation of mineralocorticoid receptor by Ubc9. Journal of Biological Chemistry 282 1998-2010.

Young M \& Funder JW 2000 Aldosterone and the heart. Trends in Endocrinology and Metabolism 11 224-226.

Young MJ, Lam EY \& Rickard AJ 2007 Mineralocorticoid receptor activation and cardiac fibrosis. Clinical Science 112 467-475.

Yudt MR \& Cidlowski JA 2002 The glucocorticoid receptor: coding a diversity of proteins and responses through a single gene. Molecular Endocrinology 16 1719-1726.

Zennaro MC, Le Menuet D \& Lombes M 1996 Characterization of the human mineralocorticoid receptor gene $5^{\prime}$-regulatory region: evidence for differential hormonal regulation of two alternative promoters via nonclassical mechanisms. Molecular Endocrinology 10 $1549-1560$.

Zennaro MC, Farman N, Bonvalet JP \& Lombes M 1997 Tissue-specific expression of alpha and beta messenger ribonucleic acid isoforms of the human mineralocorticoid receptor in normal and pathological states. Journal of Clinical Endocrinology and Metabolism 82 1345-1352.

Zennaro MC, Souque A, Viengchareun S, Poisson E \& Lombes M 2001 A new human MR splice variant is a ligand-independent transactivator modulating corticosteroid action. Molecular Endocrinology 15 1586-1598.

Received in final form 9 March 2009

Accepted 19 March 2009

Made available online as an Accepted Preprint 19 March 2009 